\title{
The Role of Printed Media Regarding the Position of Woman in Albania
}

\author{
Isida Hoxha \\ Universiteti Luigj Gurakuqi, \\ isidahaxhi@hotmail.com
}

\begin{abstract}
This paper analyzes the content of independent printed media regarding the woman position in Albania. Performing out its functions, media often reflects the stereotypes of the society; one of these stereotypes is the reflection of gender, especially woman. Even if media plays an important role in the process of socialization, it also has the obligation to transmit and make public a proper and good image of individuals. The most important function of media is that, while reflecting the society, it should not create or transmit stereotypes and should not play a role on their reinforcement. Related the gender stereotype and media role on this issue I have chosen the case study called Ajshe Vata. This case study is important because it represents the story of the murder of a young girl in Albania called Ajshe Vata. The importance of this case lays in the importance that media showed to this death. Therefore, the research question of this study is; what is the role of independent printed media in Albania in the cases when woman is the victim? Do the stereotypes created by society get reinforced by the printed media? Methodology used in this study will be discourse analyses in the printed media which at the same time will be the main theory of this paper. I will choose the independent newspapers during the period October 2012, when the case takes place.
\end{abstract}

Keywords; discourse analyses, gender and media, media discourse, gender discourse, stereotypes

\section{Introduction}

Media should play not only the informational function but at the same time also the creative function for the audience for the perspectives it presents. It distributes messages that reach in a short time at a large number of people. Its role in the chose theme to be treated is very significant, because it can influence in changing of perceptions of people according to gender differences, man and wife. To understand the role of media not from the theory but from practice is selected the case of Ajshe Vata. This case study serves to analyze the work done from the printed press by having in focus the characteristics of this case, which represents many problems of the woman in the Albanian society, and the way, which is chosen to make them publicly. The study of this case by analyzing the representation of events serves to answer the research question raised above in relation to stereotypes created from the society, which are enforced from media.

\section{Discourse analyses}

In the paper we are referring the importance that analyze of the text has by firstly saying that the discourse analyzes has different version by referring to two main division where one includes the detailed analyzes of text and the other not. The approach that is used refers to the attitude of Fairclough who emphasizes that "my approach to discourse analysis is based upon the assumption that language is an irreducible part of social life, dialectically interconnected with other elements of social life, so that social analysis and research always has to take account of language. "(Fairclough 2003:2). This study relies on the discourse analyzes by taking into consideration that this analyzes is not only related to linguistic characteristics of the text, but by referring the relationship language-social practice as elements that interact through structuring at each other. "The term discourse (in what is widely called 'discourse analysis')signals the particular view of language in use... as an element of social life which is closely interconnected with other elements" (Fairclough 2003:3) 
Discourse analyzing can operate with different analytical tools but in this article to study the role of woman in Albania in printed media through the selected study case are used: lexical, sentence structures in the title of the article by referring to the verbs and noun phrases in function of participants and circumstances. According to Mills (1995:143-144)"the study of transitivity is concerned with how actions are represented; what kind of actions appear in a text, who does them and to whom they are done". Transitivity is used for the text as one of the most important tools of representation by focusing on participants, the process in itself and circumstances.

\section{Media discourse and social construction of news.}

The language used in the content of the printed press is not neutral and is not simply telling the facts. This happens because the journalists in the process of their job firstly do a selection of events, happenings through the process of selection by referring some criteria which help in its determination that will be public or not. The second important element is the transformation that is done to the selected event by adopting with the characteristics of the medium and the used ways by referring to different kinds of mediums to make news: "News is a representation of the world in language; because language is a semiotic code, it imposes a structure of values, social and economic in origin, on whatever is represented; and so inevitably news, like every discourse, constructively patterns that of which it speaks. News is a representation in this sense of construction; it is not a value free reflection of 'facts'" ( Fowler 1991:4) The representation of world in the texts of news, in a democratic society is related to the freedom of press to bring different point of views because of economical, political, social factors, which are not released, from the prejudices. "Journalism has social effects; through its power to create the issues of agendas and public discourse, it can enforce the beliefs; it can create people's opinion not only in the world but also in their country and the role in the world; or if it doesn't shape your opinion in a particular issue it can slightly influence those you have thoughts on. " (Richardson 2007: 13) Mental categorization is a process that is present in all people and through that people can classify everything based on their understandable experiences or not, which direct us toward stereotypes. Our relationship in the role of public with printed, visual media etc influences even more this process, by considering the values of the news, which can enforce our stereotypes.

\section{Discourse discrimination, gender and power}

As was said above the categorization serves as a platform to build the discrimination, which is related to unequal opportunities for individuals that are involved and are part of certain groups. Different factors, where the most important are cultural, social factors make possible for us to categorize not in relation to individual characteristics of the person but also the referential like gender, religion faith, race etc. Media discourse serves to maintain and enforce the discrimination based on groups of reference, by referring to language in use in relation to existing ideology. Ideologies are representations of aspects of the world which can be shown to contribute to establishing, maintaining and changing social relations of power, domination and explanation (Fairclough 2003:9). The presentation of women in printed media is related to the categorization of this group by referring mainly to attribute such as irrational, powerless, depended on other people, which are realized according to the statement that "linguistic usage is sexist, responding to the ideological paradigms in discourse which assign women special, deviant status in certain respects" (Fowler 1991:97). This representation enforces the existing ideology in relation to stereotyping of the woman in the Albanian society as I presented during the study.

\section{Analyzes}

\section{Types of violation and psychology}

The inequality between females and males is presented into different forms changing it into one of the actual problems not only in undeveloped countries but also in those developed ones. This case study gives some important elements in relation to created stereotypes from the society and enforced by media. Firstly, Ajshe Vata is an eighteen years old girl who raised in a controlled family till that point that it was impossible for her to go out of the house without another person and have a social life in related to the characteristics of her age, by being in this way a victim of psychological violation. The violation in family despite the form it appears is too difficult to make known, because a large number of cases are not reported. Secondly, as it appears from the development of the event she was a victim of sexual violation in a young age (14 years old) which changed into "a relationship" between her and the abuser until the moment she becomes a victim of murder from the same person because of an unwanted pregnancy. 
A victim of different forms of violations, Ajshe Vata creates a psychological profile which is totally described in the moment when she is part of the extreme decision in relation to her life "You mustn't just kill me, but should cut my head, disappear and even burn me in this way my family would not recognize me and know that I was pregnant" (Musaj, L. 2012:7)

By being part of a community where the members recognize existing stereotypes built from the society, she knows what is the best and the worst inside this context. The lexical used by Ajshe Vata enforces this approach, because the used vocabulary to describe relies mainly on naming such as: girl, religious, model, sociable, pupil of Medresse etc which are accompanied with the verbs: cooked, washed, helped, substituted the figure of mother for sisters and brothers. With the pre-scale of the information, we have attitudes such as: "I recognized her, but never crossed my mind that she was such a girl... I cannot believe because she was a good and beautiful girl". (2012: 3)

\section{The presentation of the news as a social problem}

An evident element in printed media in Albania is the lack of treatment of themes like physical, psychological, sexual, violation, pedophile abusing in the social context as part of the chronicles. It is needed a particular event to move some mechanisms in relation to the inclusion of particular authorities like psychologists, representatives of civil society etc who can express meaningful messages in relation to the definition of perceptions, reactions, incorrect behaviors, where very often the victim blames herself, is blamed or prejudiced from others. In this context the role of media is not be honored because the victim rarely is kept from the mediatisation and then when it should be ensured the anonym. In chosen problem and its treatment in the independent printed press is improved because they do analyze and ask the experts of the field. Sources from different fields write by giving important information in relation to determine what is wrong and right. Significant messages are given from psychologists who analyze such problems by considering the importance of the family and stereotyped gender roles inside it. Despite the family an important factor of the family is media, which selects to transmit or publish information not on the frame of that what is important for the public but relying on sensation and the spectacular side of the event.

\section{Titles}

"Media chooses the event to report according to value or importance of the news, which should fulfill some certain criteria; therefore, the news is not simply what has happened but that which is presented as valuable and important to be "news" (Fowler 1991:13). Since the first moment when the vents happens they decide on the title, headline which talk about the nature of crime by describing in details the way how is the crime committed and peculiarities such as:"Revealed the confession of the father of the murder girl without head. The head of victim is cut continuously with a knife" (2012: 1)

The doubts on the responsible people are focused on the crime inside the family where the attention is concentrated on the father of the victim and secondly on the crime committed from passion. The heading "AND from 40 men. The killing of the student, in crime another female" (2012:1). This title expresses different information from other newspapers in relation to the amount of people that can be involved in the crime. By referring to the titles used, we have build the profile of the victim where is continuously emphasized the pregnancy in the representation of this event as a cause for the murder and for the attitude of the family. After such information is public, there are titles like this: "Father of Ajshja: My daughter dishonored me, I don't mourn since I heard that she was pregnant" (2012:1) or "The daughter dishonored me, there is no mourning in my house" (Çela, 2012:10)

The continuing of investigations from the competent institutions reveals the identification of the person, whose declarations are public in relation to the reason of murder, which leads to the negation of the victim to abort. Despite these developments are presented news that emphasize the private life of the victim and family come pre-scaling from the first point that the girl was good, religious etc toward "She had sexual interaction during the month of Ramadan, July-August" (2012:7). In a time when Aishe Vata is presented as an ex student of Medrese, religious the publication of such information is meaningful to understand the message that the title represents to portrait the victim. Aishe Vata is not blamed for the actions that have emerged the process in its development, but through the titles is continuously and dominantly emphasized, the shame that comes from such situation, where the victim turns into the main social actor, the consequences of the action which influence on the "honor" of the family. 


\section{Lexical and transitivity}

To make a discourse analyze one of the most important tool is the lexical used in the building of the text. Language is rich in different words which can be used during the text to explain a purpose, action, attribute, naming etc which permit to choose one of them. The way how we decide to name others during the text might have significant meanings, in relation to characteristics that everyone has, as part of social categories because we have to do with selection. The journalist during his work can decide to emphasize the possession in a certain category by not using another category. Reisigl and Wodak have illustrates that choosing to describe an individual (or a group) as one thing or as another can serve many different psychological, social or political purposes...(2001:47). Referential strategies are a good way to understand the process of representation in relation to social actors involved in the event. By referring to the discourse of the analyzes of the text through these analytic tools we see that Ajshe Vata is mainly named with words: girl, religious, model, sociable, lovable, student of Medrese, victim. Meanwhile the author of the crime is named with the words: maniac, monster, 80 years old, killer, elderly. Through the analyzes of text by referring to lexical and referential strategies over participants (Part of transitivity) during the development of the work results that Ajshe Vata is addressed positive social values and the author of the crime is associated non human negative values. The process in itself is the second element that is studied when we use transitivity. The verbs are grouped into different categories so we have different types of processes over which can be build a sentences such as verbal, mental, relative process and the materials. The used verbs during the building of the text are mainly focused on the words: discovered, killed, cut, was, shamed, dishonored. By referring to the forms of the verbs that are included in the material process it can be noticed that in the case when we have to do with the building construct in active form (the subject before the object) also in the construct in the passive form (the object before the subject or the elimination of the subject) the information remains the same. Differently from other cases where the usage of passive form can be used with a purpose in this study the elimination of the subject, does not give facilities to the author of the event. The circumstances in which is connected the process are the third element of transitivity. The usage of adverbs and phrasal verbs in the studied newspapers does not change in relation to the role of the author Shaban Norja because all discourses are made from the same point of view for his responsibility and murder. Whereas in relation to Ajshe Vata the discourse is built by giving information over the circumstances of the process in the role of the victim (in tools and the way how the crime was committed) and on her private life focusing on the interaction good girl-pregnant! The representation of that what the journalists decide to turn into news, by studying the discourse through chosen tools relies on information which force the created stereotype in the society that a good girl, single cannot be pregnant. The constant focus on her pregnancy, the consequences of this action over the family, and their reactions where the main word is shame, dominate and are more important that the referential strategies and the lexical, which is not negative in the text, used for Vata.

The categorization that is done to Ajshe Vata through other elements mentioned is related with the origin of her family from a village of Kukes (a small town in the north of Albania) and with her residence Xhafzotaj (a village in Durres). This categorization helps in the enforcement of the created stereotypes from the Albanian society through citizen-villager and in the concrete case village girl, by referring to the strategy of Van Dijk, we and they.

\section{The sensation.}

Professional practices of production of discourse are related to the respecting of principles and ethical codes. All ethical codes despite their differences have similarities the production of a product, the ethic news. The journalists during the representation of the event are oriented toward the usage of title where the focus is the sensation. The usage of this element is not something casual but well studied, because it is known the importance of titles in printed media, where very often the reader just reads the title of the article. This event by being related with the values of the news when one of them is the continuity remained on first pages of newspapers for a week, by sensationalizing the violence and brutality. The organizational necessity for news, the wish for sensation in relation to the attraction of public interest, produces and reproduces information which is interesting for the public. One of the ethical principles is that "they should show maturity toward people who cannot be aware for the consequences that have the declarations they give". (2006:3). The analyze results that the declarations from the author Shaban Norja don't only touch the private life of the victim but also that of her sisters. In the newspaper Panorama is published: "Another important element discovered is that the 80 years old has declared that has sexual interaction with older daughters of Vatafamily"(Deliaj\&Musaj,2012:2) The sisters of the victim now are participants by being involved just for a spectacular report of the event. In an interview the father of Aishe Vates, declares that "... the public opinion is manipulated" (IInica 2012:6) He says some facts that are not real in relation to the things the author had bought to the victim (by referring the declarations of the author which enforce the stereotype of loving 
for interest, money), with the declarations toward other girls of the family, which suffer the destroying of their families. Interesting is the fact that all these violations that Vata reports are public in the same newspaper where is given the interview. Such messages influence that the Albanian reality remains unchangeable as e result of the role of media. The representation of this event does not change anything from the created stereotypes by referring to these main categories of readers: the category which enforces the gender existing stereotypes man-woman. Part of the public are people who can be in similar situations of violation who are in the middle of choosing to speak and the risk of becoming public by referring to previous examples and exposed from media or the silence with the hope that everything remains unknown and unheard. The perception in this case is not the reporting of such cases because of shame that can include other familiars, but the silence.

\section{Conclusions}

The study of this case study through the representation of the event shows two messages. Firstly, media through the involvement of psychologists realizes the treatment of the event as a social problem by ensuring the positive message.

Secondly, the study of discourse produced by journalist relies on information, which enforces the created stereotypes in the society. This realizes through the usage of two methods. The direct method refers to the way of creating the titles and including of individuals that are not actor of this event orienting toward the production of a sensational discourse.

The indirect method is related to continuously focus on private life and pregnancy of the victim. The consequences of this action on familiars and their reactions where the main thing is shame, dominate and are stronger than referential strategies and not negative lexical used in the text for the victim.

\section{References}

Fairclough, N (2003) Analysing discourse, Textual analysis for social research. London: Routledge

Fowler, R (1991) Language in the news. London: Routledge

Reisigl, M. \&Wodak, R (2001) Discourse and Discrimination: Rhetorics of racism and anti-semitism. London: Routledge

Richardson, J (2007), Analysing newspapers, An approach from critical discourse analysis New York: Palgrave Macmillan

Mills, S (1995) Feminist stylistic. London: Routledge

AND from 40 men. The killing of the student, in crime another female" Panorama, 13. 10. $2012 \mathrm{f.} 1$

Çela, Lindita,"The daughter dishonored me, there is no mourning in my house" Shekulli, 14. 10. 2012 f. 10

Deliaj, Etleva\&Musaj Leonidha"Another important element discovered is that the 80 years old has declared that has sexual interaction with older daughters of Vata family", Panorama, 16. 10. 2012 f. 2

"Father of Ajshja: My daughter dishonored me, I don't mourn since I heard that she was pregnant" Panorama 14. 10. 2012 f1

Innica, Elisabeta "Father of Aishe Vates: The truth of my family" Panorama 22. 10. 2012 f. 6

"I recognized her, but never crossed my mind that she was such a girl... I cannot believe because she was a good and beautiful girl", Gazeta Shqiptare 15. 10. 2012 f. 3

Musaj, Leonidha "You mustn't just kill me, but should cut my head, disappear and even burn me in this way my family would not recognize me and know that I was pregnant" Panorama 17. 10. 2012, f. 7

"She had sexual interaction during the month of Ramadan, July-August" Panorama, 14. 10. 2012 f 7 
"Revealed the confession of the father of the murder girl without head. The head of victim is cut continuously with a knife" Gazeta Shqiptare 13. 10. 2012, f. 1

"She had sexual interaction during the month of Ramadan, July-August" Panorama, 14. 10. $2012 \mathrm{f} 7$

ISHM (2006), Kodi Etik i Medias Shqiptare, (Online) Available: http://w. w. wosce. org/sq/albania/21235/Kodi Etik i Medias Shqiptare 